\title{
X-linked inhibitor of apoptosis protein and active caspase-3 expression patterns in antral follicles in the sheep ovary
}

\author{
Hollian R Phillipps ${ }^{1,3}$, Ilona C Kokay ${ }^{1,2}$, David R Grattan ${ }^{1,2}$ and Peter R Hurst ${ }^{1,3}$ \\ ${ }^{1}$ Department of Anatomy, School of Medical Sciences and ${ }^{2}$ Centre for Neuroendocrinology, University of Otago, \\ Dunedin 9016, New Zealand and ${ }^{3}$ Centre for Reproduction and Genomics, Invermay Agricultural Centre, \\ Mosgiel 9053, New Zealand
}

Correspondence should be addressed to P R Hurst at Department of Anatomy, University of Otago, PO Box 913, Dunedin 9054, New Zealand; Email: peter.hurst@anatomy.otago.ac.nz

\begin{abstract}
X-linked inhibitor of apoptosis protein (XIAP) interacts with caspases to inhibit their activity, thereby providing a potential mechanism for regulation of granulosa cell apoptosis occurring during follicular atresia. The aim of this study was to determine the presence and localization of XIAP mRNA and protein content in the sheep ovary and compare these expression patterns with active caspase-3 protein in the same antral follicles. Romney ewe estrous cycles $(n=25)$ were synchronized with 2-3 Estrumate injections and ovarian tissue collected during the luteal and follicular phases of the cycle. The presence of XIAP mRNA was confirmed by RT-PCR using laser capture microdissected ovarian cell samples. XIAP mRNA was subsequently localized by in situ hybridization histochemistry and XIAP and active caspase-3 protein visualized by immunohistochemistry. In antral follicles extensive XIAP localization was evident in both granulosa and thecal cells. In contrast, mRNA expression was widespread in granulosa cells and only detected in thecal tissue from a small proportion of antral follicles. Active caspase-3 and XIAP comparative expression analysis showed positive XIAP mRNA expression in all late luteal phase (day 14) follicles, despite varying levels of active caspase-3 protein. A proportion of follicular phase (days 15 and 16 ) follicles, however, showed an inverse expression relationship at the protein and mRNA levels in both granulosa and thecal tissue, as did XIAP protein in day 14 follicles. These results suggest high XIAP may prevent activation of caspase-3, thereby regulating follicular atresia in antral follicles and could potentially be utilized as a marker of follicular health.
\end{abstract}

Reproduction (2011) 142 855-867

\section{Introduction}

Atresia, a degenerative process involving granulosa cell apoptosis, is the eventual fate of the majority of ovarian follicles during reproductive years (Hussein 2005). Apoptosis can be induced either within the cell mitochondria or by death inducing ligands, such as Fas ligand, binding to cell surface receptors. This leads to activation of a number of signaling pathways in which caspases are pivotal molecules (Hussein 2005). Caspases are cysteine proteases capable of cleaving target substrates at aspartic acid residues, promoting cellular breakdown. These proteases act either as initiators, such as caspase-9 or effectors (executioners), for example, caspase-3, depending on their position in the apoptotic signaling cascade. Caspases display a functional connection whereby upstream initiators can cleave and activate downstream effectors (Slee et al. 1999, Kumar 2007). Inhibition of caspase activation can occur at the level of zymogen conversion and downstream, averting active protease interaction with specific substrates, as reviewed by (Callus \& Vaux 2007). Previous studies in mice, rat, cow, and human ovaries have shown active caspase- 3 is a common executer of apoptosis in antral staged follicles (Boone \& Tsang 1998, Matikainen et al. 2001, Fenwick \& Hurst 2002, Nicholas et al. 2005, Hurst et al. 2006). Consequently, this protein can be utilized as a reliable marker of the early stages of follicular atresia.

Inhibitor of apoptosis proteins (IAPs), initially identified during genetic screening of $p 35$ homologs during baculoviral infection, were subsequently found in additional species, including yeast, fruit fly, and humans (Crook et al. 1993, Hay et al. 1995, Roy et al. 1995, Duckett et al. 1996, Uren et al. 1999). These proteins are characterized by one or more baculoviral IAP repeat (BIR) zinc-binding domain(s) and found to be endogenous regulators of apoptosis (Clem \& Miller 1994, Duckett et al. 1996, Hinds et al. 1999, Mace et al. 2009). There has been considerable debate concerning the underlying mechanism of this regulation. X-linked IAP (XIAP), CIAP1, and CIAP2 have been shown to bind caspases via their BIR2 or BIR3 domains (Deveraux et al. 1997, Roy et al. 1997); however, only XIAP has the ability to potently inhibit enzymatic activity of caspases-3, -7 , and -9 
via these interactions (Sun et al. 2000, Shiozaki et al. 2003, Eckelman \& Salvesen 2006). The mechanism and key residues responsible for tight XIAP/caspase binding have been characterized (Sun et al. 1999, Huang et al. 2001, Riedl et al. 2001, Scott et al. 2005). XIAP inhibits active caspase- 3 and $-7^{\prime}$ s active site by a two-site binding mechanism involving the BIR2 domain and preceding linker sequence (Chai et al. 2001, Riedl et al. 2001, Scott et al. 2005). Active caspase-9 inhibition is also achieved by two-site binding, however, this occurs independent of caspase- 9 's active site, via interaction of the BIR3 domain with monomeric procaspase-9's dimeric interface preventing homodimer formation (Shiozaki et al. 2003).

XIAP expression has been localized in the ovary of rats (Li et al. 1998, Lai et al. 2003, Lareu et al. 2003) and pigs (Cheng et al. 2008) and observed in vitro in ovarian cell types, including human ovarian surface epithelial (OSE) cells (Johnson et al. 2004) and bovine granulosa cells (Kayamori et al. 2009). A positive expression gradient during follicle development has been observed in pigs and rats, in which the highest levels occur at the antral follicle stage (Li et al. 1998, Cheng et al. 2008). Furthermore, comparative analyses in these species involving XIAP mRNA and/or protein expression levels and degree of follicular atresia as measured by the ratio of progesterone/estradiol- $17 \beta$ in follicular fluid or by TUNEL expression have implicated XIAP as a potential key regulator of granulosa cell apoptosis (Li et al. 1998, Cheng et al. 2008). In rat granulosa cells, FSH has been shown to promote XIAP expression in vivo and in vitro, further supporting an anti-apoptotic role for XIAP in this cell type (Asselin et al. 2001, Wang et al. 2003). Moreover, XIAP can induce AKT upregulation in rat granulosa cells implicating involvement of the phosphatidylinositol 3-kinase signaling pathway, which is known to promote cell survival (Asselin et al. 2001).

The aim of this study was to determine the presence and localization of XIAP mRNA and protein and to investigate changes in XIAP levels in relation to follicular atresia using active caspase-3 protein expression as a marker of granulosa cell apoptosis in the sheep ovary. Sheep were utilized as they provide the opportunity for easy manipulation of reproductive cycles in a large animal model, contain ovaries with high follicle numbers at a range of different stages and like humans they predominantly undergo a single ovulation per cycle. Furthermore, mutations in important reproductive genes, such as $B M P 15$, cause female infertility in both humans and sheep, but reduce ovulation rates in rodents (Shimasaki 2006). Consequently, sheep are an appropriate model to test the hypothesis that XIAP levels will be elevated in healthy antral follicles compared with atretic antral follicles and will show an inverse relationship with active caspase-3 protein expression in the same antral follicles.

\section{Results \\ RT-PCR}

RNA was extracted from whole ovary tissue and laser capture microdissection (LCM) isolated cell type samples collected on days 10,14, and 16 of the estrous cycle. Presence of the $\beta$-actin (741 bp) transcript was used to confirm RT success. Then positive anti-Müllerian hormone $(A M H ; 342 \mathrm{bp}) \mathrm{RT}$-PCR product bands were used as a granulosa cell-specific marker to confirm absence of contamination in isolated thecal, stromal, and luteal cells, respectively, before downstream reactions (Fig. 1A and B). XIAP expression was present, evident as a $357 \mathrm{bp}$ product band in all isolated granulosa, thecal, stromal, and luteal cell LCM samples and whole ovary tissue extracts collected during the luteal phase (days 10 and 14) and follicular phase (day 16) of the estrous cycle (Fig. 1C-E).

\section{In situ hybridization histochemistry for XIAP}

A proportion of antral follicles showed positive XIAP mRNA expression in granulosa cells (Table 1 and Fig. 2A, B, and $\mathrm{E}-\mathrm{H}$ ). Hybridization to XIAP mRNA in thecal tissue was infrequent and granulosa

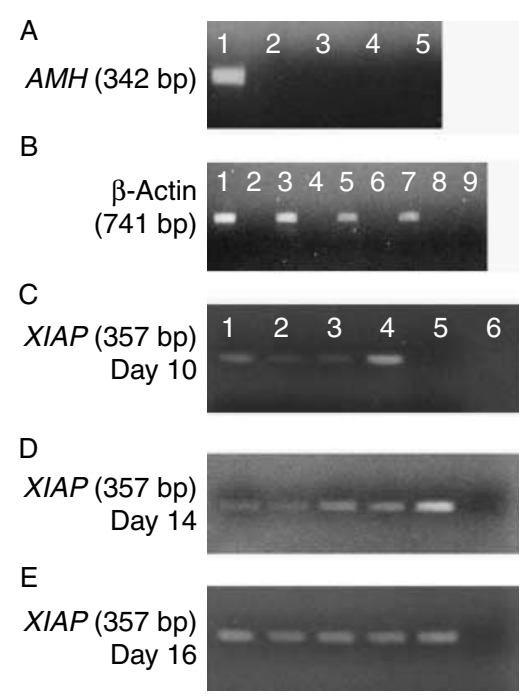

Figure 1 XIAP expression in ovarian tissue detected by RT-PCR. (A and B) Quality control analysis. A, AMH; B, $\beta$-actin. (A) Lane 1, granulosa cells; lane 2, thecal cells; lane 3, stromal cells; lane 4, luteal cells; lane 5, RNase-free water control. (B) Lane 1, granulosa cells; lane 2, granulosa cell RT negative; lane 3, thecal cells; lane 4, thecal cell RT negative; lane 5, stromal cells; lane 6, stromal cell RT negative; lane 7, luteal cells; lane 8, luteal cell RT negative; lane 9, RNase-free water control. RT-PCR analysis of XIAP transcripts in ovarian tissue collected days $10(\mathrm{C}), 14$ (D), and 16 (E) of the estrous cycle. (C) Lane 1, granulosa cells; lane 2, thecal cells; lane 3, stromal cells; lane 4, whole ovary tissue extract; lane 5, RNase-free water control; lane 6, blank. (D and E) Lane 1, granulosa cells; lane 2, thecal cells; lane 3, stromal cells; lane 4, luteal cells; lane 5, whole ovary tissue extract; lane 6, RNase-free water control. Oligonucleotide primer sets used are listed in Table 3. 
Table 1 Comparison between active caspase-3 immunopositive granulosa cell numbers and the presence or absence of X-linked inhibitor of apoptosis protein (XIAP) mRNA expression in the same days 14, 15, and 16 antral follicles in the sheep ovary.

\begin{tabular}{|c|c|c|c|c|c|}
\hline \multirow[b]{2}{*}{ Follicle numbers } & \multirow[b]{2}{*}{$\begin{array}{c}\text { Follicle } \\
\text { diameters }(\mathrm{mm})\end{array}$} & \multirow[b]{2}{*}{$\begin{array}{c}\text { Disruption of granulosa } \\
\text { cell layers }\end{array}$} & \multirow{2}{*}{$\begin{array}{c}\text { Number of active } \\
\text { caspase-3 immunoreactive } \\
\text { granulosa cells }\end{array}$} & \multicolumn{2}{|c|}{$X I A P$ expression } \\
\hline & & & & $\begin{array}{l}\text { Granulosa } \\
\text { cells }\end{array}$ & $\begin{array}{l}\text { Thecal } \\
\text { cells }\end{array}$ \\
\hline \multicolumn{6}{|c|}{ (A) Day 14 antral follicles } \\
\hline 1 & 1.32 & Yes & 9 & Yes & No \\
\hline 2 & 0.72 & Yes & 485 & Yes & No \\
\hline 3 & 4.00 & No & 10 & Yes & No \\
\hline 4 & 2.29 & Yes & 401 & Yes & Yes \\
\hline 5 & 0.62 & No & 2 & Yes & Yes \\
\hline 6 & 0.33 & Yes & 128 & Yes & No \\
\hline 7 & 0.91 & No & 18 & Yes & No \\
\hline 8 & 0.45 & Yes & 97 & Yes & No \\
\hline 9 & 0.73 & No & 127 & Yes & No \\
\hline \multicolumn{6}{|c|}{ (B) Day 15 antral follicles } \\
\hline 1 & 0.58 & Yes & 502 & No & No \\
\hline 2 & 0.83 & Yes & 13 & No & No \\
\hline 3 & 3.50 & No & 8 & Yes & No \\
\hline 4 & 1.19 & No & 0 & Yes & Yes \\
\hline 5 & 0.35 & Yes & 0 & No & No \\
\hline \multirow{2}{*}{\multicolumn{6}{|c|}{ (C) Day 16 antral follicles }} \\
\hline & & & & & \\
\hline 1 & 0.41 & Yes & 17 & No & No \\
\hline 2 & 0.36 & No & 1 & Yes & Yes \\
\hline 3 & 0.46 & No & 7 & No & No \\
\hline 4 & 0.84 & No & 7 & Yes & No \\
\hline 5 & 0.63 & No & 10 & Yes & No \\
\hline 6 & 0.83 & No & 7 & No & No \\
\hline 7 & 0.34 & Yes & 41 & No & No \\
\hline 8 & 0.79 & No & 60 & No & No \\
\hline
\end{tabular}

cells within the same antral follicles with antisense probe hybridization in thecal cells also showed positive expression (Table 1 and Fig. 2E-H). XIAP antisense probe hybridization, however, was not detected at earlier follicle stages, including primordial, primary, and preantral follicles. Variable levels of hybridization were apparent in positive antral follicles present in the same section plane at all three tissue collection time points during the estrous cycle (Fig. 2A and B). Furthermore, antral follicles containing granulosa and thecal cells with increased XIAP mRNA content showed changes in expression intensity across tissue layers (Fig. 2G and H). Granulosa cells closer to the basement membrane or in the theca interna showed higher XIAP levels compared with granulosa cells alongside the antral space or in the theca externa. The XIAP antisense probe hybridized to oocytes $(n=3)$ within antral follicles containing high granulosa cell $X I A P$ levels (Fig. 2E and F), however, no expression was evident in oocytes $(n=3)$ within antral follicles showing minimal XIAP mRNA expression. No convincing positive mRNA expression was observed in the stroma or OSE, however, low hybridization was evident in luteal cells (Fig. 2C and D). Sections treated with the sense probe showed no specific hybridization in any cell type (Fig. $2 \mathrm{l}$ and J).

\section{Immunohistochemistry for XIAP and active caspase-3}

XIAP immunohistochemistry provided higher detection sensitivity than in situ hybridization histochemical studies as the protein was evident in follicles from the primary stage onwards and in thecal tissue surrounding a high proportion of antral follicles (Table 2 and Fig. 3A-E, $6 \mathrm{~A}, \mathrm{~B}, \mathrm{E}$, and G). Expression was predominantly cytoplasmic in both granulosa and thecal cells and infrequent possible nuclear or perinuclear localization was apparent (Fig. 3F). Moreover, localization patterns did not change at any of the tissue collection time points during the estrous cycle. All antral follicles showed positive staining (Table 2) but levels of expression (as seen with mRNA levels) varied between follicles present in the same tissue section. Similar changes in expression intensity to that observed in in situ hybridization histochemical studies across granulosa and thecal cell layers from cells alongside the antral space to the theca externa was also apparent. Protein expression also localized to OSE cells (Fig. 3G), some stromal cells surrounding small follicles and luteal cells (Fig. $3 \mathrm{H}$ ). No positive immunoreactivity was observed in negative or IgG control sections (Fig. 3I and J).

Active caspase-3 protein expression was detected primarily in granulosa cells in follicles from the early antral stage onwards (Fig. 4A-E). At the cellular level, its 


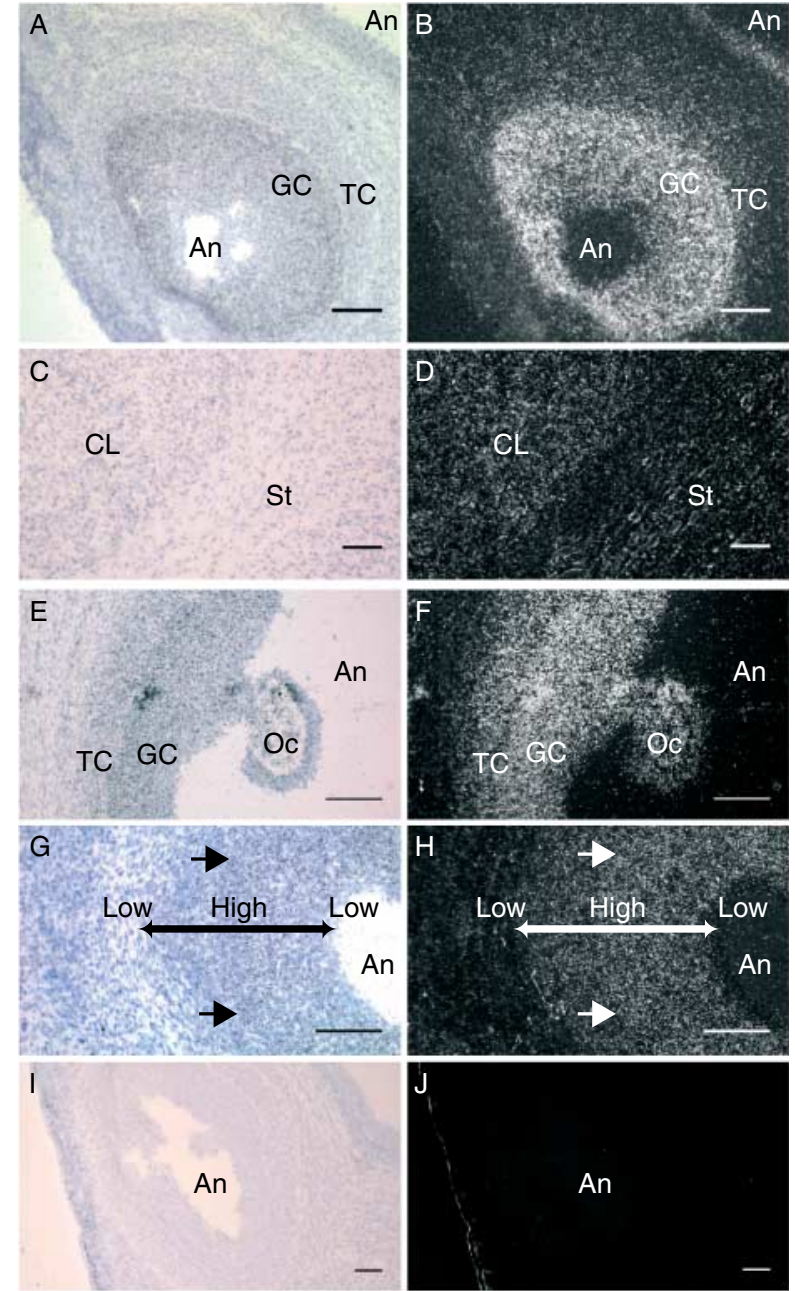

Figure 2 Corresponding bright and dark field images showing XIAP mRNA localization. (A and B) High levels of positive hybridization for $X I A P$ mRNA in granulosa cells in an antral follicle. Low thecal cell expression is also evident. A second antral follicle on the same section with lower XIAP expression in granulosa cells is shown in the superior aspect of the image. (C and D) Low hybridization to XIAP is evident in luteal cells $(\mathrm{CL})$. (E and F) An increased signal is shown in an antral follicle oocyte, cumulus oophorus and surrounding granulosa and thecal cells. ( $\mathrm{G}$ and $\mathrm{H}$ ) Variable XIAP mRNA expression is shown in granulosa and thecal cells (indicated by a line with two arrowheads). Cells closer to the basement membrane and in central cell layers show elevated mRNA expression compared with cells adjacent to the antral space or in theca externa. Images (I and J) depict an antral follicle in a section treated with a sense probe. Scale bars A, B, I, and J, $200 \mu \mathrm{m}$; $\mathrm{C}-\mathrm{H}, 100 \mu \mathrm{m}$. An, Oc, GC, TC, and St indicate antral space, oocyte, granulosa cells, thecal cells, and stroma respectively. Arrows in $(\mathrm{G}$ and $\mathrm{H})$ indicate basement membrane.

localization was similar to XIAP, being predominantly cytoplasmic and a small number of cells showing nuclear/perinuclear expression (Fig. $4 \mathrm{~F}$ and G). Two distinct active caspase- 3 immunopositive granulosa cell localization patterns were apparent. In some follicles immunopositive cells were mostly located adjacent to the antral space (Fig. 4F), while in others expression was scattered more evenly throughout granulosa cell layers
(Fig. 4G). Occasional staining of single thecal cells was observed, however, only a small proportion of thecal cells (one to two immunopositive cells on a single section plane) showed active caspase-3 protein expression (Fig. 4E) and no signal was detected in oocytes or stroma. Furthermore, active caspase-3 immunopositive cells were detected in some corpora lutea and were predominantly located in the structure's periphery (Fig. 4H). No specific staining was observed on negative control slides and some IgG control sections showed a faint light pink background hue (Fig. $4 \mathrm{I}$ and J).

\section{Comparison between XIAP mRNA and protein expression and active caspase- 3 protein expression in days 14, 15, and 16 antral follicles}

A semi-quantitative comparative analysis was undertaken on XIAP mRNA and active caspase-3 protein expression in $n=23$ antral follicles $(0.3-4 \mathrm{~mm}$ in diameter). XIAP mRNA expression was detected in all late luteal phase (day 14) follicles studied, despite varied active caspase- 3 immunoreactivity (Table 1 and Fig. 5A-F). In a proportion of follicular phase (days 15 and 16) follicles, however, XIAP mRNA showed an inverse relationship with active caspase- 3 protein expression (Table 1 and Fig. 5G-L). Subsequent comparison of XIAP and active caspase-3 protein expression patterns in $n=22$ antral follicles $(0.1-1.3 \mathrm{~mm}$ in diameter) demonstrated that the presence of active caspase-3 immunopositive cells did not always infer complete absence of XIAP expression in days 14 and 15 antral follicle granulosa cells (Table 2). A more consistent reduction in XIAP expression with increasing active caspase-3 immunopositive granulosa cells was observed in follicles collected on day 16 of the cycle (Table 2 and Fig. 6). XIAP protein expression in thecal tissue from these same follicles at all three collection points followed a consistent pattern of reduction becoming progressively localized to the interna layer with increasing active caspase- 3 immunoreactivity and virtually absent when active caspase-3 protein levels were high (Fig. 6).

\section{Discussion}

This study aimed to test the hypothesis that XIAP levels will be elevated in healthy antral follicles compared with atretic antral follicles and will show an inverse relationship with active caspase- 3 protein expression in the same antral follicles. Presence of XIAPmRNA was initially determined in whole ovary tissue extracts and subsequently by LCM of specific ovarian cell types. Positive $\mathrm{XIAP}$ mRNA and protein expression in ovarian follicles and the corpus luteum is consistent with findings from previous experiments in rats and pigs (Li et al. 1998, Wang et al. 2002, Lareu et al. 2003, Cheng et al. 2008). Evidence of positive XIAP expression at the protein level in stromal tissue surrounding small follicles, however, was not 
Table 2 Comparison between active caspase-3 immunopositive granulosa cell numbers and the intensity of X-linked inhibitor of apoptosis protein (XIAP) immunoreactivity in granulosa and thecal cells from the same days 14, 15, and 16 antral follicles in the sheep ovary ${ }^{\mathrm{a}}$.

\begin{tabular}{|c|c|c|c|c|c|}
\hline \multirow[b]{2}{*}{ Follicle numbers } & \multirow[b]{2}{*}{$\begin{array}{c}\text { Follicle } \\
\text { diameters (mm) }\end{array}$} & \multirow{2}{*}{$\begin{array}{l}\text { Disruption of } \\
\text { granulosa } \\
\text { cell layers }\end{array}$} & \multirow{2}{*}{$\begin{array}{c}\text { Number of active } \\
\text { caspase-3 immunoreactive } \\
\text { granulosa cells }\end{array}$} & \multicolumn{2}{|c|}{ XIAP expression } \\
\hline & & & & $\begin{array}{l}\text { Granulosa } \\
\text { cells }\end{array}$ & $\begin{array}{l}\text { Thecal } \\
\text { Cells }\end{array}$ \\
\hline \multicolumn{6}{|c|}{ (A) Day 14 antral follicles } \\
\hline 1 & 0.24 & No & 2 & +++ & ++ \\
\hline 2 & 0.52 & Yes & 425 & ++ & ++ \\
\hline 3 & 0.50 & Yes & 132 & + & ++ \\
\hline 4 & 1.04 & Yes & 27 & + & + \\
\hline 5 & 0.72 & No & 0 & ++ & +++ \\
\hline 6 & 0.13 & No & 1 & ++ & ++ \\
\hline \multicolumn{6}{|c|}{ (B) Day 15 antral follicles } \\
\hline 1 & 0.18 & No & 0 & +++ & +++ \\
\hline 2 & 0.31 & Yes & 587 & ++ & + \\
\hline 3 & 0.30 & No & 3 & ++ & ++ \\
\hline 4 & 0.25 & No & 3 & +++ & +++ \\
\hline 5 & 0.22 & No & 1 & ++ & ++ \\
\hline 6 & 0.34 & Yes & 0 & + & - \\
\hline 7 & 0.46 & Yes & 2 & + & + \\
\hline 8 & 0.11 & No & 0 & +++ & ++ \\
\hline 9 & 0.24 & No & 2 & +++ & +++ \\
\hline 10 & 1.32 & No & 6 & +++ & ++ \\
\hline \multicolumn{6}{|c|}{ (C) Day 16 antral follicles } \\
\hline 1 & 0.44 & No & 2 & +++ & ++ \\
\hline 2 & 0.20 & Yes & 0 & + & - \\
\hline 3 & 0.43 & Yes & 15 & + & + \\
\hline 4 & 0.42 & No & 0 & +++ & +++ \\
\hline 5 & 0.62 & Yes & 503 & + & + \\
\hline 6 & 0.60 & No & 3 & +++ & +++ \\
\hline
\end{tabular}

${ }^{a}(-)$, Indicates no XIAP immunoreactivity; $(+)$, indicates occasional XIAP immunoreactivity; $(++)$, frequent XIAP immunoreactivity; $(+++)$, extensive XIAP immunoreactivity.

recorded in an earlier study investigating XIAP expression in the rat indicating a possible difference existing between rodent and ruminant species (Li et al. 1998).

The apparent absence of XIAP expression in primordial follicles suggests it acts downstream of initial recruitment during folliculogenesis, having a role specific to growing follicles. Moreover, XIAP immunopositive stromal cells observed surrounding primary follicles in this study suggests a potential role in recruitment and/or differentiation of thecal cells, which may be additional to its anti-apoptotic function. Involvement in thecal cell differentiation has also been suggested following observations of higher XIAP expression in rat thecal cells compared with granulosa cells in growing follicles (Lai et al. 2003). Furthermore, XIAP has been associated with differentiation of other cell types, including human monocytes, rat luteal cells and in regulating the rate of alveolar differentiation in the mouse mammary gland during late pregnancy (Lareu et al. 2003, Tamm et al. 2004, Olayioye et al. 2005). In this study, XIAP mRNA and protein localization in antral follicle granulosa cells collected during the follicular phase (days 15 and 16) of the cycle generally showed similar expression patterns. Moreover, positive expression observed in mural and cumulus granulosa cells and also thecal tissue in antral follicles supports findings in rat studies (Li et al. 1998, Lai et al. 2003).
An increase in XIAP expression associated with follicle maturation as shown in the rat ovary (Li et al. 1998), however, was not observed in this study. Immunoreactivity levels in follicles smaller than the preantral stage were not described in the rat study whilst here in sheep intense staining was detected in some small follicles. Variation in XIAP mRNA and protein expression intensity across cell layers, from granulosa cells alongside the antral space to the theca externa in antral follicles observed in this study suggests additional factors within the follicular fluid and/or stromal tissue immediately surrounding follicles may be contributing to XIAP's effect in the follicle.

Detection of XIAP expression in luteal cells in this study suggests a potential role in the development and maintenance of this structure, as has been proposed in rats (Lareu et al. 2003). Moreover, a gradual reduction in XIAP expression levels has been implicated as a potential regulatory mechanism for corpora lutea regression via apoptosis in rats following pregnancy (Lareu et al. 2003).

Variable XIAP expression levels in a proportion of antral follicles showing differing degrees of follicular atresia observed in this study has also been recorded in earlier studies in rats and pigs (Li et al. 1998, Cheng et al. 2008). Here in sheep active caspase-3 protein was utilized as an early atresia marker as in vivo and in vitro analyses have shown its expression to precede DNA 
A
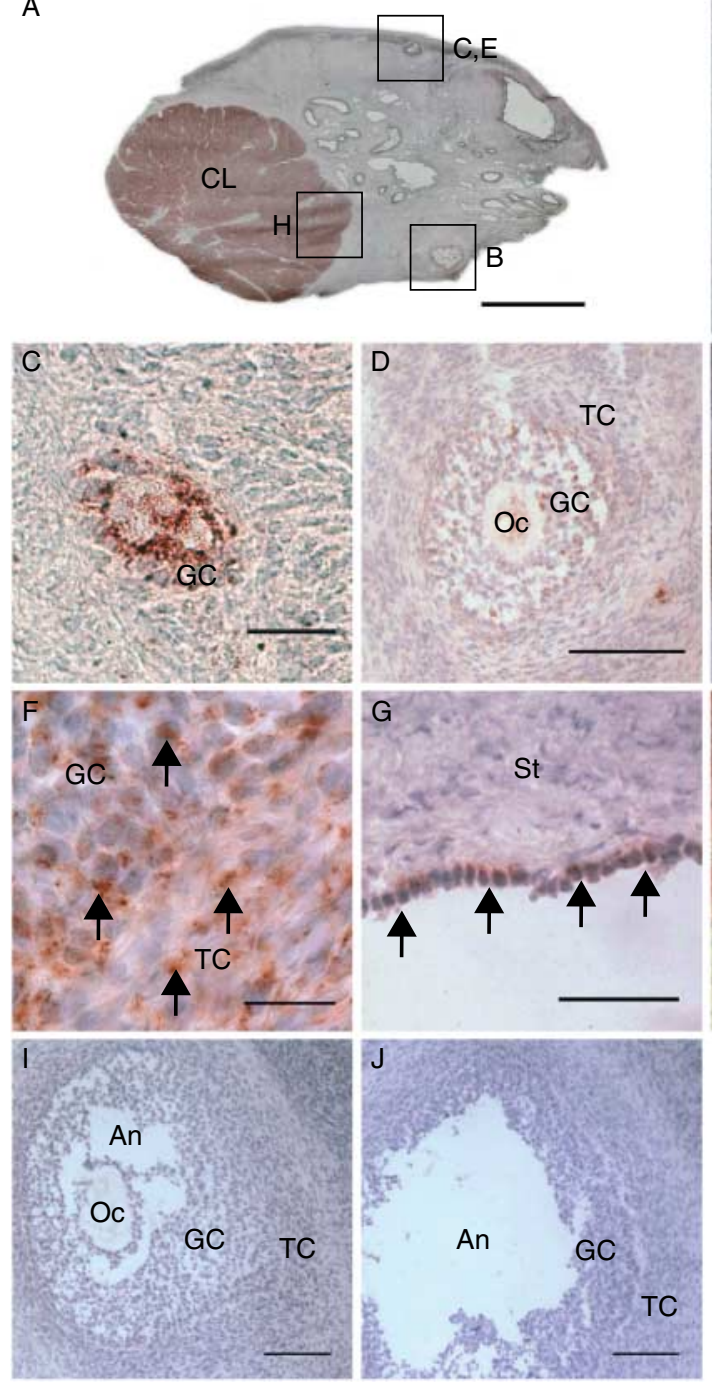
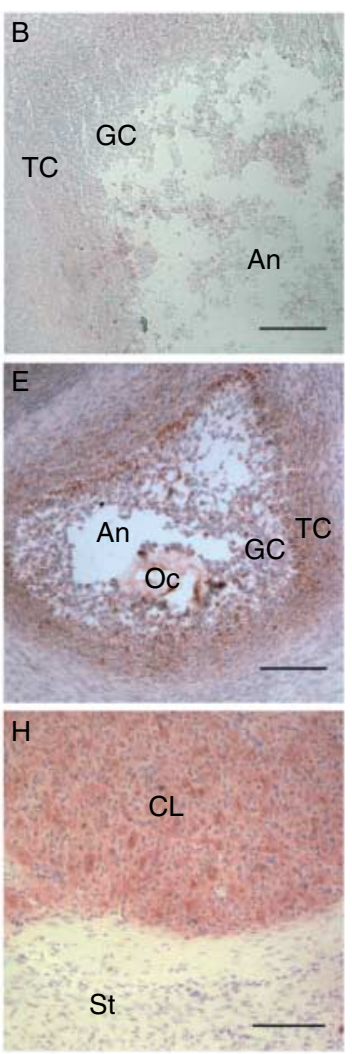

St

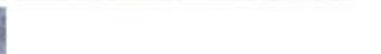

Figure 3 Immunohistochemical localization of XIAP. Positive immunoreactivity is denoted by red particulate stain (AEC). (A) Image of a whole ovary section (adjacent to that shown in Fig. 4A) showing the pattern of XIAP expression. Intense immunoreactivity is evident in the corpus luteum (CL). The black boxes indicate the location of follicles and luteal cells depicted in (B, C, E, and $\mathrm{H}$ ) respectively. (B) An antral follicle with low XIAP expression in granulosa and thecal cell layers (compare with active caspase-3 protein expression in the same follicle Fig. 4B). Images (C-E) show positive XIAP immunoreactivity in granulosa cells in preantral follicles (C and D) and an early antral follicle (E; compare (C-E) with active caspase- 3 protein expression in the same follicles in Fig. 4C-E). Immunoreactive thecal cells are also evident in (D and $E$ ). (F) A high magnification image showing predominant cytoplasmic localization of XIAP in both granulosa and thecal cell layers in an antral follicle. Arrows indicate examples of intense immunostaining. The OSE $(\mathrm{G})$ and luteal cells $(\mathrm{H})$ also showed positive XIAP immunoreactivity. Arrows in (G) indicate immunopositive cells. Images (I and J) depict antral follicles in negative and IgG control sections respectively. Scale bars A, $3000 \mu \mathrm{m} ; \mathrm{C}$ and F, $20 \mu \mathrm{m} ; \mathrm{B}, \mathrm{D}, \mathrm{E}$, and $\mathrm{H}-\mathrm{J}, 100 \mu \mathrm{m}$; and $\mathrm{G}, 50 \mu \mathrm{m}$. An, Oc, GC, TC, CL, and St indicate antral space, oocyte granulosa cells, thecal cells, corpus luteum, and stroma respectively. fragmentation and the majority of apoptotic morphological changes, including cell shrinkage (Janicke et al. 1998, Matikainen et al. 2001, Hurst et al. 2006). Active caspase-3 localization observed in this study is consistent with expression patterns observed in mice and humans (Matikainen et al. 2001, Fenwick \& Hurst 2002, Hurst et al. 2006). The levels of active caspase-3 protein expression are regulated by XIAP through inhibition, however, a number of factors also influence XIAP expression levels. The ring zinc finger domain present in XIAP has been implicated as playing a self-regulatory role as it exhibits $E_{3}$ ligase activity and facilitates selective apoptosis signal induced proteasome dependent self-degradation (Yang et al. 2000, Liston et al. 2001). Furthermore, a number of antagonists, such as second mitochondrial activator of caspases/direct IAPbinding protein with low pl (Smac/DIABLO; Chai et al. 2000, Wu et al. 2000) and high-temperature requirement A2/Omi (HtrA2/Omi) also regulate XIAP/caspase interactions. Consequently, XIAP synthesis, stability and inhibition will lead to changes in active caspase-3 protein levels, which will affect the eventual fate of the follicles.

In healthy rat follicles XIAP is predominantly located in the nuclei of granulosa cells, whereas in atretic follicles it undergoes a localization shift and is primarily distributed in the cytoplasm (Li et al. 1998). A change in intracellular localization associated with atresia, however, was not observed in this study and may reflect species differences. Widespread XIAP expression in thecal tissue in healthy follicles, which becomes increasingly localized to interna layers and eventually disappears as atresia progresses in this study, is interesting. In cows, mice, and humans active caspase- 3 immunopositive thecal cells are rarely observed (Matikainen et al. 2001, D'Haeseleer et al. 2006, Hurst et al. 2006), which is in agreement with results here in sheep. Moreover, the reason for elevated XIAP thecal expression in healthy follicles observed in several studies has not been addressed (Li et al. 1998, Asselin et al. 2001, 
A
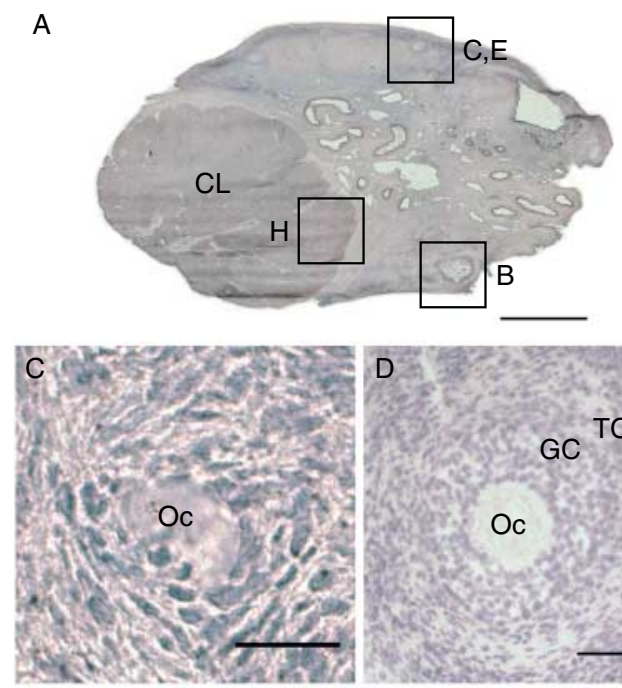

$\mathrm{F}$
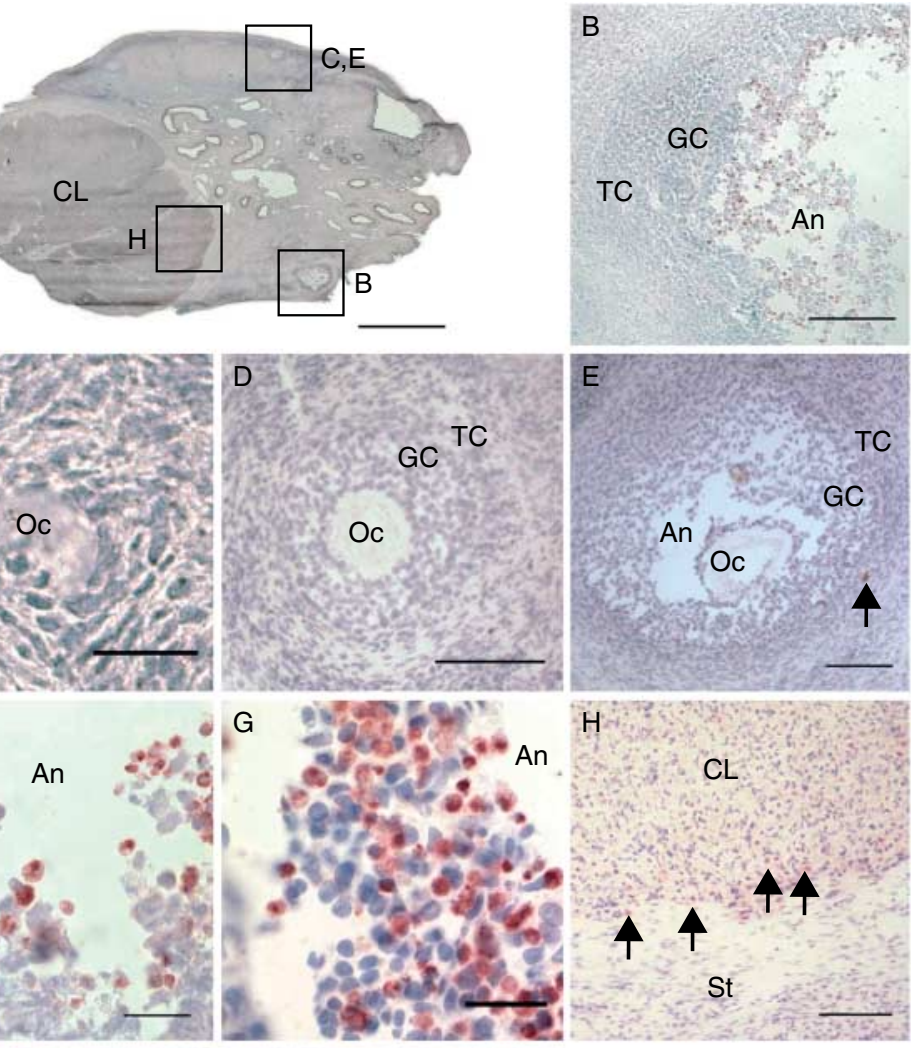
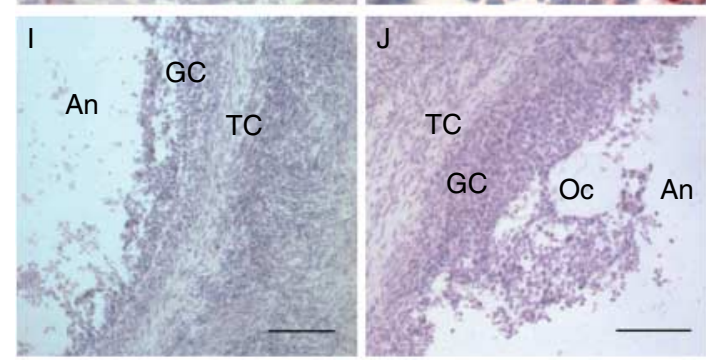

Figure $4 \mathrm{Immunohistochemical} \mathrm{localization} \mathrm{of} \mathrm{active} \mathrm{caspase-3} \mathrm{protein} \mathrm{in} \mathrm{the} \mathrm{sheep} \mathrm{ovary.} \mathrm{Positive} \mathrm{immunoreactivity} \mathrm{is} \mathrm{denoted} \mathrm{by} \mathrm{red} \mathrm{particulate}$ stain (AEC). (A) Image of a whole ovary section (adjacent to that shown in Fig. 3A) showing the pattern of active caspase-3 protein expression. The black boxes indicate the location of follicles and luteal cells depicted in (B, C, E, and H) respectively. (B) An antral follicle with numerous active caspase-3-positive granulosa cells (compare with XIAP expression in the same follicle, Fig. 3B). Images (C and D) show the absence of active caspase-3 protein in preantral follicles (compare with XIAP expression in same follicles Fig. 3C and D). An early antral follicle in (E) contains a single immunopositive thecal cell (indicated by arrow, compare with XIAP expression in the same follicle, Fig. 3E). Images (F and G) show higher magnification views of two different active caspase-3 immunopositive granulosa cell patterns in antral follicles. (F) Shows immunoreactivity predominantly presents adjacent to the antral space and (G) depicts a more even distribution throughout granulosa cell layers. (H) Luteal cells showing positive staining (examples indicated by arrows). Images (I and J) atretic antral follicles from negative and IgG control sections, respectively, showing absence of staining. Scale bars A, $3000 \mu \mathrm{m} ; \mathrm{C}, \mathrm{F}$, and G, $20 \mu \mathrm{m}$; and B, D, E, and H-J, $100 \mu \mathrm{m}$. An, Oc, GC, TC, CL, and St indicate antral space, oocyte granulosa cells, thecal cells, corpus luteum, and stroma respectively.

Lai et al. 2003). XIAP may be acting as a thecal cell survival factor in response to the cytotoxic challenge presented by development of associated vasculature. Alternatively, low active caspase-3 activity associated with this tissue type may just be evidence of an evolutionary redundant mechanism as a study in rats found the endonuclease DNase I responsible for DNA fragmentation is absent in thecal cells or could represent an alternate mechanism of action, such as XIAP acting primarily at the level of caspase-9, although this requires further investigation in ovaries (Boone \& Tsang 1997). Low caspase-9 mRNA expression has only been detected in theca interna layers from advanced atretic pig follicles (Matsui et al. 2003).

Expression of XIAP mRNA in all late luteal phase (day 14) antral follicles with varying levels of active caspase-3 immunoreactivity suggests a potential redundant or unspecified role for XIAP may exist during this phase. Protein level observations indicate transcription of XIAP is differentially regulated at this time point. It may be that 


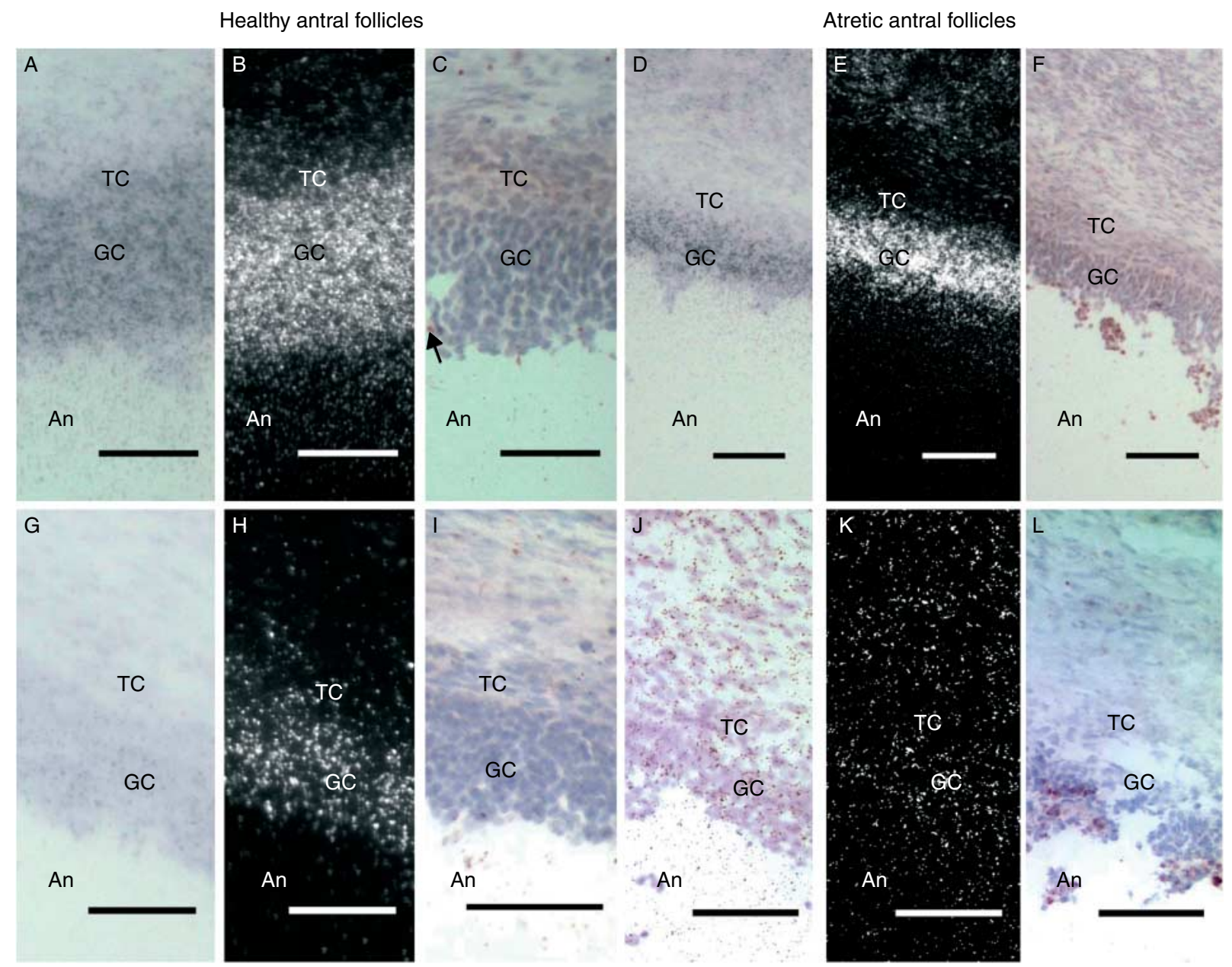

Figure 5 Comparison between XIAP mRNA and active caspase-3 protein expression patterns. Positive active caspase-3 immunoreactivity is denoted by red particulate stain (AEC). (A-C and $\mathrm{G}-\mathrm{I}$ ) show corresponding bright ( $\mathrm{A}$ and $\mathrm{G}$ ) and dark (B and $\mathrm{H}$ ) field images of extensive XIAP mRNA localization and corresponding low active caspase-3 protein expression levels (C and I) in the same day 14 (follicle 5, Table 1A; A-C) or 15 (follicle 3, Table 1B; G-I) antral follicles. Arrow in (C) indicates immunopositive cell, no positive staining is apparent in the field of view shown in (I). (D-F and $\mathrm{J}-\mathrm{L}$ ) depict corresponding bright ( $\mathrm{D}$ and $\mathrm{J}$ ) and dark ( $\mathrm{E}$ and $\mathrm{K}$ ) field images with an active caspase-3 comparison ( $\mathrm{F}$ and $\mathrm{L}$ ) showing high active caspase3 expression levels in the same day 14 (follicle 2 Table 1A; D and E) or 15 (follicle 1, Table 1B; J and K) antral follicles. The granulosa cell layers in the day 14 antral follicles show high XIAP mRNA expression ( $\mathrm{D}$ and $\mathrm{E}$ ), despite the presence of numerous active caspase-3 immunopositive granulosa cells (F). Hybridization to XIAP in granulosa and thecal cell layers is by contrast absent in the day 15 follicle (J and K) that contains high active caspase-3 protein expression (L). Scale bars A-C and G-L, $50 \mu \mathrm{m} ; \mathrm{D}-\mathrm{F}, 100 \mu \mathrm{m}$. An, TC, and GC indicate antral space, thecal cells, and granulosa cells respectively.

antral follicles during the luteal phase retain the ability to regulate follicular fate in response to a specific stimulus, despite the presence of active caspase- 3 immunopositive cells. Once in the follicular phase, however, irreversible selection for dominance associated with ovulation may block this. Consequently, despite varied results, a proportion of follicles sampled at this time point in this study showed an inverse XIAP/active caspase-3 expression relationship suggesting maintenance of XIAP might be a characteristic of selected follicles. Antral follicles in this study not showing an inverse expression relationship may be undergoing terminal atresia, by which time active caspase- 3 expression is no longer detectable. This is in agreement with findings in advanced atretic hamster follicles, in which a reduction in active caspase-3 expression was evident compared with early atretic follicles (Moffatt-Blue et al. 2006). Alternatively, as active caspase-3 protein expression occurs during the early stages of atresia, there may be a delay in downregulation of XIAP until active caspase-3 expression reaches a threshold concentration in a follicle. Furthermore, the variability in results obtained from the XIAP/active caspase-3 expression pattern analysis could be due to inclusion of both follicles able to respond to gonadotrophic hormones but not require this support for growth (gonadotrophin-responsive) and follicles reliant on $\mathrm{FSH}$ and $\mathrm{LH}$ for growth and development (gonadotrophin-dependent) which may 


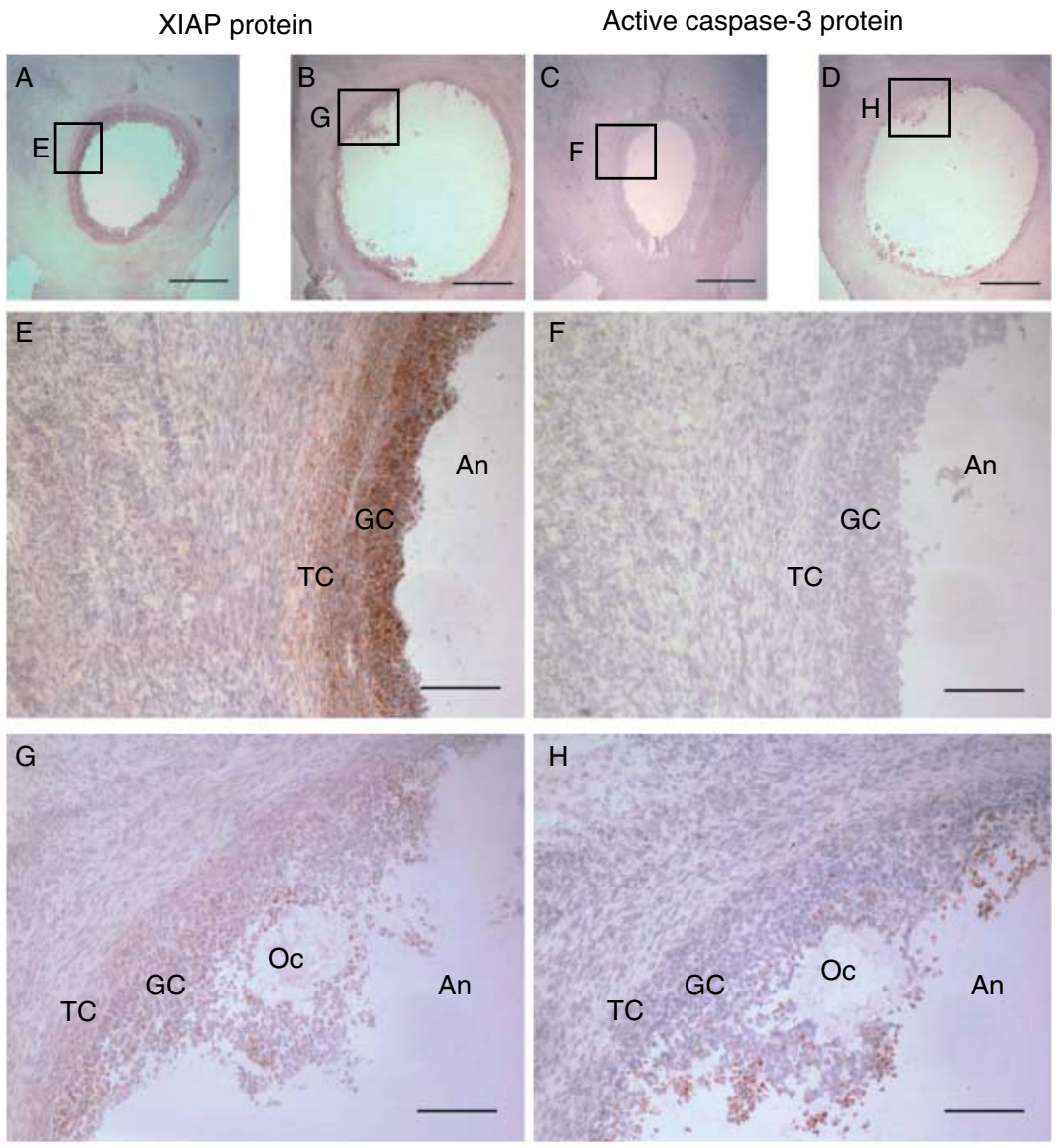

Figure 6 Comparison between XIAP and active caspase- 3 protein immunolocalization in healthy and atretic day 16 antral follicles. Images (A-D) show a view of the entire follicle used in this comparison. The black boxes labeled (E-H), indicate the region of follicle wall depicted in the corresponding images (E-H). (E) Extensive XIAP was detected in both granulosa and thecal cell layers in the healthy antral follicle. (F) A section from the same healthy antral follicle had no active caspase-3 protein immunoreactivity. (G) Low XIAP expression is shown in granulosa cells in an atretic antral follicle. (H) A large number of active caspase-3 immunopositive granulosa cells are evident in the same follicle. Scale bars A-D, $200 \mu \mathrm{m} ; \mathrm{E}-\mathrm{H}$, $100 \mu \mathrm{m}$. An, Oc, TC, and GC indicate antral space, oocyte, thecal cells, and granulosa cells respectively.

undergo atresia in response to differential stimuli (Scaramuzzi et al. 1993). Alternatively, unique properties associated with individual follicles at similar developmental stages may have also contributed to the variability. Therefore, future studies focused on specific antral follicle developmental time points encompassing both early and late stage atretic markers are likely to provide a clearer understanding of XIAP's role in atresia and its interaction with caspase targets.

In summary, this study has described in detail XIAP and active caspase- 3 ovarian localization patterns at the end of the luteal phase and during the follicular phase in the sheep estrous cycle. XIAP mRNA and protein were detected in thecal tissue, a cell type displaying weak or trace active caspase- 3 expression indicating either XIAP shows increased efficiency in active caspase-3 inhibition or XIAP could have alternate predominant caspase inhibition targets, such as caspase- 9 in this cell type. Alternatively, XIAP may have a different role in these cells, such as thecal cell recruitment/differentiation, which requires further investigation. A proportion of antral follicles showing low active caspase- 3 and high XIAP levels and vice versa recorded in this study suggests XIAP may act as a regulator of follicular atresia in the sheep ovary, however, further studies are required to characterize this interaction.

\section{Materials and Methods}

\section{Animals}

Ethics approval for all procedures involving animals was granted by the Invermay Animal Ethics Committee (AEC 11484 and AEC 11 109) in accordance with the 1999 Animal Protection (Codes of Ethics Conduct) Regulations of New Zealand. Two- to seven-year-old Romney ewes $(n=25)$ with no history of reproductive genetics were obtained from AgResearch Limited, Invermay, Mosgiel, Dunedin, New Zealand. Ewe estrous cycles were synchronized by 2 or $30.6-0.7 \mathrm{ml}$ i.m. injections of Estrumate (active ingredients cloprostenol $250 \mu \mathrm{g} / \mathrm{ml}$, Southern Veterinary Supplies, Christchurch, New Zealand) given at 9- to 10-day intervals to promote luteolysis. Synchronization success was determined by running a teaser ram wearing a harness containing marker chalk with the ewes, confirming estrus (day 0 ) by visual observation of the presence of a mark on the ewe's hindquarter. All ewes had access to pasture and water ad libitum and were transported to an abattoir up to $72 \mathrm{~h}$ before being killed. Ewes were killed either by a lethal 10-20 ml i.v. injection of sodium pentobarbitone (Pentobarb $500,500 \mathrm{mg} / \mathrm{ml}$, National Veterinary Supplies Ltd, East Tamaki, Auckland, New Zealand) or by captive bolt and ovaries collected during the luteal phase (days 10 and 14) and follicular phase (days 15 and/or 16) of the subsequent natural cycle following synchronization. 


\section{Ovary processing}

Ovaries were divided into halves or quarters and either snap frozen in liquid nitrogen for RT-PCR or frozen slowly in optimal cutting temperature embedding compound (Tissue-Tek, Sakura Finetek, Inc., Torrance, CA, USA) over liquid nitrogen cooled isopentane for laser capture microdissection (LCM), immunohistochemistry, and in situ hybridization histochemistry. Frozen tissue was stored at $-80{ }^{\circ} \mathrm{C}$ for up to 6 months before use. Adjacent sections (12 and $6 \mu \mathrm{m}$ ) were cut in a cryostat at $-22{ }^{\circ} \mathrm{C}$ from tissue collected on days $14(n=3$, end of luteal phase), 15 ( $n=3$, follicular phase), and 16 ( $n=3$, follicular phase) of the cycle for in situ hybridization histochemistry and immunohistochemistry respectively. Sections were thaw mounted onto Superfrost plus-coated slides (ThermoFisher Scientific, Australia Pty Ltd, Scoresby, VIC, Australia) and stored at $-80{ }^{\circ} \mathrm{C}$ until use. For LCM, sections $(8 \mu \mathrm{m})$ were cut in a cryostat at $-22^{\circ} \mathrm{C}$ from ovaries collected on days $10(n=3), 14$ $(n=3)$, and $16(n=3)$ of the cycle and thaw mounted onto u.v. treated u.v. absorbent polyethylene terephthalate membrane frame slides (Leica Microsystems, Wetzlar, Germany). Sections were stored at $-80{ }^{\circ} \mathrm{C}$ overnight.

\section{RNA extraction from whole ovary tissue}

Total RNA was extracted from $50 \mathrm{mg}$ fresh frozen whole ovary pieces collected during the luteal phase (days $10(n=3)$ and 14 $(n=3))$ and follicular phase (day $16(n=3))$ of the cycle by a method based on that originally described by Chomczynski (Chomczynski 1993, Chomczynski \& Sacchi 2006). Tissue was homogenized in TRIzol reagent (GibcoBRL, Grand Island, NY, USA) and phases separated using chloroform. RNA was precipitated in isopropanol and washed in $75 \%(\mathrm{v} / \mathrm{v})$ ethanol. RNA was resuspended in Tris-ethylenediaminetetraacetic acid buffer and stored at $-80{ }^{\circ} \mathrm{C}$. Total RNA concentration and purity was determined by u.v. spectrometry and integrity confirmed by agarose gel electrophoresis.

\section{Laser capture microdissection}

Sections were thawed at room temperature, postfixed in ice-cold acetone and stained with HistoGene (Arcturus, Mountain View, CA, USA). A Leica laser capture microdissection (LMD) system was used to cut out separate areas of granulosa, thecal, stromal, and luteal cells (if present), letting each cell type drop via gravity into $20 \mu \mathrm{l}$ lysis buffer (Qiagen, Doncaster, VIC, Australia) in underlying caps of PCR tubes (200 $\mu$ l capacity). Once all cells of interest had been collected tubes were capped, centrifuged briefly and incubated at
$-20{ }^{\circ} \mathrm{C}$ for $1 \mathrm{~h}$. RNA extraction was undertaken in accordance with the manufacturer's instructions using an RNeasy Micro Kit (Qiagen).

\section{RT-PCR}

RNA extracted from whole ovary pieces and LCM samples was reverse transcribed using Superscript III first-strand synthesis system for RT-PCR with random hexamers (Invitrogen, Auckland, New Zealand) according to the manufacturer's instructions. Resultant cDNA samples were stored at $-20{ }^{\circ} \mathrm{C}$ until use.

Oligonucleotide primer sets were designed using the Primer3 input website (http://frodo.wi.mit.edu/) for ovine $X I A P, A M H$, and $\beta$-actin using mRNA sequences obtained from either the NCBI GenBank database or kindly provided by Michelle French (AgResearch Limited) and custom made by Invitrogen (Table 3). PCR reactions were made up to $25 \mu \mathrm{l}$ final volume consisting of $1 \times$ Amplitaq Gold PCR master mix (Applied Biosystems, Melbourne, VIC, Australia), $1 \mu \mathrm{l}$ whole ovary tissue cDNA or $2 \mu \mathrm{l}$ LCM cDNA sample, $500 \mathrm{~nm}$ of each forward and reverse primer, and $10.5 \mu \mathrm{l}$ (whole ovary tissue RNA extract) or $9.5 \mu \mathrm{l}$ (LCM RNA extract) RNase-free water. These reactions were run in a thermocycler (Corbett Research, Mortlake, NSW, Australia) and subjected to initial denaturation at $94{ }^{\circ} \mathrm{C}$ for $2 \mathrm{~min}$, then repeated cycles (Table 3 for cycle number) of denaturation $\left(94{ }^{\circ} \mathrm{C}, 30 \mathrm{~s}\right)$, annealing $\left(54{ }^{\circ} \mathrm{C}(X I A P)\right.$, $57^{\circ} \mathrm{C}(\mathrm{AMH}$ and $\beta$-actin), $30 \mathrm{~s})$, and extension $\left(72{ }^{\circ} \mathrm{C}, 30 \mathrm{~s}\right.$ $(X I A P$ and $A M H), 45 \mathrm{~s}$ ( $\beta$-actin)), followed by a final extension step at $72{ }^{\circ} \mathrm{C}$ for $10 \mathrm{~min}$. PCR products were run on a $1 \%(\mathrm{w} / \mathrm{v})$ agarose gel and amplicon identity confirmed by DNA sequencing.

\section{In situ hybridization for XIAP mRNA: 35-S labeled RNA probe preparation}

The same XIAP primer set used for RT-PCR (Table 3), with T7 or SP6 promoter sequences incorporated onto the $5^{\prime}$ ends was used to generate templates by RT-PCR using whole ovary cDNA. Resultant cDNA was purified using a QIAquick PCR purification kit (Qiagen) according to the manufacturer's instructions. RNA probes labeled with [35-S] UTP were produced by transcribing cDNA using a riboprobe in vitro transcription kit (Promega, Madison, WI, USA) with either T7 polymerase (antisense RNA probe) or SP6 polymerase (sense (control) RNA probe). Mini Quick spin RNA columns (Roche Applied Science, Indianapolis, IN, USA) were used to remove unincorporated nucleotides.

Table 3 Ovine oligonucleotide primer sets and number of amplification cycles used for RT-PCR.

\begin{tabular}{|c|c|c|c|c|}
\hline Primer names & Sequences & $\begin{array}{l}\text { Amplicon } \\
\text { size (bp) }\end{array}$ & $\begin{array}{l}\text { GenBank accession } \\
\text { number }\end{array}$ & Cycle number \\
\hline$X I A P$ forward & 5'-TTGTTGTGGTGGGAAGTTGA-3' & 357 & - & 32 (whole tissue) \\
\hline$X I A P$ reverse & 5'-TGTTGTTCCCAAGGGTCTTC-3' & & & 38 (LCM samples) \\
\hline$A M H$ forward & 5'-CAACACCCTTGCTGAGGTTC-3' & 328 & NM_173890 & 40 (LCM samples) \\
\hline$A M H$ reverse & 5'-AGTAACAGGGCTGGGGTCTT-3' & & & \\
\hline$\beta$-Actin forward & $5^{\prime}$-AACCGTGAGAAGATGACCCAG-3' & 741 & U39357 & 37 (whole tissue) \\
\hline$\beta$-actin reverse & 5'-СТССТGСТTGСТGАTССАСАTC-3' & & & 38 (LCM samples) \\
\hline
\end{tabular}




\section{Hybridization}

Sections were thawed at $55{ }^{\circ} \mathrm{C}$ for $5 \mathrm{~min}$, postfixed in $4 \%(\mathrm{w} / \mathrm{v})$ paraformaldehyde in $0.1 \mathrm{M}$ phosphate buffer (PB) for $20 \mathrm{~min}$ and washed twice in $0.5 \times$ saline-sodium citrate (SSC, $75 \mathrm{mM}$ sodium chloride, $7.5 \mathrm{mM}$ trisodium citrate dihydrate). Immersion in $1 \times$ Triethanolamine with $0.25 \%(\mathrm{v} / \mathrm{v})$ acetic anhydride was undertaken to acetylate amino groups in the tissue, followed by two washes in $2 \times$ SSC and optimization of probe penetration using a graded ethanol series and chloroform. Sections were air-dried, covered with $100 \mu$ l hybridization buffer $(50 \%(\mathrm{v} / \mathrm{v})$ formamide, $0.3 \mathrm{M}$ sodium chloride, $1 \times$ Denhardt's solution, $20 \mathrm{mM}$ Tris, $5 \mathrm{mM}$ EDTA, 10\% (w/v) dextran sulfate, and $100 \mathrm{mM}$ dithiothreitol) and prehybridized for $2 \mathrm{~h}$ at $42{ }^{\circ} \mathrm{C}$. RNA probes $\left(1.0 \times 10^{6} \mathrm{cpm}\right.$ in $120 \mu \mathrm{l}$ hybridization buffer (final concentration)) were combined with tRNA (50 $\mathrm{g}$ /section, Roche Applied Science) and denatured at $95^{\circ} \mathrm{C}$ for $3 \mathrm{~min}$ before loading $20 \mu$ antisense or sense probe/tRNA/hybridization buffer solution onto appropriate sections containing the prehybridization mixture. Sections were incubated at $55^{\circ} \mathrm{C}$ for $24 \mathrm{~h}$.

\section{Posthybridization}

Sections were washed in $2 \times$ SSC with $10 \mathrm{mM}$ $\beta$-mercaptoethanol (BME)-1 mM EDTA and any single or unbound RNA removed by treatment with RNase A $(20 \mu \mathrm{g} / \mathrm{l}$, Sigma-Aldrich, St Louis, MO, USA) before a prolonged wash step in $0.1 \times$ SSC with $10 \mathrm{mM}$ BME- $1 \mathrm{mM}$ EDTA for $2 \mathrm{~h}$ at $55^{\circ} \mathrm{C}$. Sections were dehydrated through a graded ethanol series, air-dried overnight and exposed to scientific imaging film (Kodak Biomax MR) for 7 days to generate autoradiographs. Each slide was dipped into LM-1 Hypercoat emulsion (Amersham Biosciences, Arlington Heights, IL, USA) and left to develop in a desiccated light safe box for 5 weeks at $4{ }^{\circ} \mathrm{C}$. Sections were developed by immersing slides in Kodak Professional D19 developer (Eastman Kodak Company, Rochester, NY, USA) for 5 min, rinsing in tap water and then submerging in Ilford Hypam rapid fixer (Harman Technology Ltd, Cheshire, UK) for $10 \mathrm{~min}$. Slides were transferred to tap water and sections counterstained with 1:4 strength Gill's haematoxylin, followed by dehydration in ethanol and drying at $42{ }^{\circ} \mathrm{C}$. Sections were cleared in xylene and coverslipped using Vectamount (Vector Laboratories, Inc., Burlingame, CA, USA). Analysis for positive hybridization was undertaken using an Olympus AX70 research grade light microscope fitted with a spot RT5 megapixel camera under light and dark field illumination.

\section{Immunohistochemistry for XIAP and active caspase-3}

Sections were thawed at room temperature and postfixed in $0.5 \%(\mathrm{w} / \mathrm{v})$ paraformaldehyde in $0.01 \mathrm{M} \mathrm{PBS}$ for $2 \mathrm{~min}$. Immersion in $0.3 \%(\mathrm{v} / \mathrm{v})$ hydrogen peroxide in methanol was used to quench endogenous peroxidases and sections covered with a blocking agent, 5\% (v/v) goat or donkey serum (SigmaAldrich) in $0.01 \mathrm{M}$ PBS for XIAP and active caspase-3, respectively, for $10 \mathrm{~min}$. A mouse monoclonal anti-XIAP primary antibody (BD Biosciences, Franklin Lakes, NJ, USA;
Ca \#610762, dilution $1: 250$ ) or a rabbit polyclonal active caspase-3 primary antibody (Cell Signaling Technology, Inc., Beverley MA, USA; Ca \#9661, dilution 1:200) both diluted in $0.01 \mathrm{M}$ PBS were loaded onto sections and incubated overnight at $4{ }^{\circ} \mathrm{C}$. Controls included negative control sections covered with $0.01 \mathrm{M}$ PBS only and IgG sections loaded with the appropriate IgG serum isotype, mouse IgG (Sigma, XIAP) and Rabbit IgG (Dako, Glostrup, Denmark; active caspase-3) diluted in 0.01 M PBS at the same concentration as the primary antibody used. Sections were incubated with either a goat biotinylated anti-mouse IgG (XIAP) or donkey biotinylated antirabbit IgG (active caspase-3; Amersham Biosciences) diluted 1:200 in $0.01 \mathrm{M}$ PBS for $30 \mathrm{~min}$. This was followed by incubation with streptavidin-biotinylated HRP 1:100 in 0.01 M PBS for $30 \mathrm{~min}$. Sections were developed using a 3-amino-9ethylcarazole chromogen kit (Sigma-Aldrich) in accordance with the manufacturer's instructions and counterstained with 1:4 Gill's haematoxylin. Slides were coverslipped using 90\% (v/v) glycerol in $0.01 \mathrm{M}$ PBS. Positive immunoreactivity in sections was analyzed using an Olympus $A \times 70$ research grade light microscope fitted with a spot RT5 megapixel camera.

\section{Semi-quantitative ovarian follicle analysis of in situ hybridization histochemistry for XIAP and immuno- histochemistry for XIAP and active caspase-3}

Ovarian follicle stages were classified based on the system described by (Lundy et al. 1999). In brief, follicles were classed as: primordial, consisting of a single layer of flattened granulosa cells; primary, containing one layer of cuboidal granulosa cells; preantral, two to five granulosa cell layers with no antral space and encircled by thecal tissue; antral follicle, containing an antral space enclosed in granulosa cell layers and surrounded by thecal tissue. Section planes containing each antral follicle with a visible oocyte and nucleolus were not always available. This meant the diameter of each follicle was determined by averaging two measurements taken from the basement membrane set at right angles to each other using a low powered image of the largest available cross section. Active caspase-3 immunopositive granulosa cell numbers were recorded for each antral follicle also being examined for the presence or absence of XIAP mRNA and intensity of protein expression. A mean count of immunopositive cell numbers present in three different sections containing the largest cross sections available for each follicle were analyzed. Resultant active caspase-3 immunopositive cell counts and morphological observation of the presence or absence of granulosa cell layer disruption were used to assess the degree of atresia in each follicle.

\section{Declaration of interest}

The authors declare that there is no conflict of interest that could be perceived as prejudicing the impartiality of the research reported.

\section{Funding}

This work was supported by a University of Otago Postgraduate Award. 


\section{Acknowledgements}

The authors thank staff at AgResearch Invermay, Mosgiel, New Zealand for their animal expertise during tissue collection and Andrew McNaughton (Department of Anatomy, University of Otago) for technical assistance with dark field microscopy.

\section{References}

Asselin E, Wang Y \& Tsang BK 2001 X-linked inhibitor of apoptosis protein activates the phosphatidylinositol 3-kinase/Akt pathway in rat granulosa cells during follicular development. Endocrinology 142 2451-2457. (doi:10.1210/en.142.6.2451)

Boone DL \& Tsang BK 1997 Identification and localization of deoxyribonuclease $\mathrm{I}$ in the rat ovary. Biology of Reproduction $\mathbf{5 7}$ 813-821. (doi:10.1095/biolreprod57.4.813)

Boone DL \& Tsang BK 1998 Caspase-3 in the rat ovary: localization and possible role in follicular atresia and luteal regression. Biology of Reproduction 58 1533-1539. (doi:10.1095/biolreprod58.6.1533)

Callus BA \& Vaux DL 2007 Caspase inhibitors: viral, cellular and chemical. Cell Death and Differentiation 14 73-78. (doi:10.1038/sj.cdd.4402034)

Chai J, Du C, Wu JW, Kyin S, Wang X \& Shi Y 2000 Structural and biochemical basis of apoptotic activation by Smac/DIABLO. Nature $\mathbf{4 0 6}$ 855-862. (doi:10.1038/35022514)

Chai J, Shiozaki E, Srinivasula SM, Wu Q, Datta P, Alnemri ES \& Shi Y 2001 Structural basis of caspase-7 inhibition by XIAP. Cell 104 769-780. (doi:10.1016/S0092-8674(01)00272-0)

Cheng Y, Maeda A, Goto Y, Matsuda F, Miyano T, Inoue N, Sakamaki K \& Manabe N 2008 Changes in expression and localization of X-linked inhibitor of apoptosis protein (XIAP) in follicular granulosa cells during atresia in porcine ovaries. Journal of Reproduction and Development $\mathbf{5 4}$ 454-459. (doi:10.1262/jrd.20088)

Chomczynski P 1993 A reagent for the single-step simultaneous isolation of RNA, DNA and proteins from cell and tissue samples. Biotechniques 15 532-537.

Chomczynski P \& Sacchi N 2006 The single-step method of RNA isolation by acid guanidinium thiocyanate-phenol-chloroform extraction: twenty-something years on. Nature Protocols 1 581-585. (doi:10.1038/ nprot.2006.83)

Clem RJ \& Miller LK 1994 Control of programmed cell death by the baculovirus genes p35 and iap. Molecular and Cellular Biology 14 5212-5222.

Crook NE, Clem RJ \& Miller LK 1993 An apoptosis-inhibiting baculovirus gene with a zinc finger-like motif. Journal of Virology 67 2168-2174.

Deveraux QL, Takahashi R, Salvesen GS \& Reed JC 1997 X-linked IAP is a direct inhibitor of cell-death proteases. Nature 388 300-304. (doi:10. 1038/40901)

D'Haeseleer M, Cocquyt G, Cruchten SV, Simoens P \& Broeck W 2006 Cell-specific localisation of apoptosis in the bovine ovary at different stages of the oestrous cycle. Theriogenology 65 757-772. (doi:10.1016/j. theriogenology.2005.07.008)

Duckett CS, Nava VE, Gedrich RW, Clem RJ, Van Dongen JL, Gilfillan MC, Shiels H, Hardwick JM \& Thompson CB 1996 A conserved family of cellular genes related to the baculovirus iap gene and encoding apoptosis inhibitors. EMBO Journal 15 2685-2694.

Eckelman BP \& Salvesen GS 2006 The human anti-apoptotic proteins CIAP1 and ClAP2 bind but do not inhibit caspases. Journal of Biological Chemistry 281 3254-3260. (doi:10.1074/jbc.M510863200)

Fenwick MA \& Hurst PR 2002 Immunohistochemical localization of active caspase- 3 in the mouse ovary: growth and atresia of small follicles. Reproduction 124 659-665. (doi:10.1530/rep.0.1240659)

Hay BA, Wassarman DA \& Rubin GM 1995 Drosophila homologs of baculovirus inhibitor of apoptosis proteins function to block cell death. Cell 83 1253-1262. (doi:10.1016/0092-8674(95)90150-7)

Hinds MG, Norton RS, Vaux DL \& Day CL 1999 Solution structure of a baculoviral inhibitor of apoptosis (IAP) repeat. Nature Structural Biology 6 648-651. (doi:10.1038/10701)

Huang Y, Park YC, Rich RL, Segal D, Myszka DG \& Wu H 2001 Structural basis of caspase inhibition by XIAP: differential roles of the linker versus the BIR domain. Cell 104 781-790.
Hurst PR, Mora JM \& Fenwick MA 2006 Caspase-3, TUNEL and ultrastructural studies of small follicles in adult human ovarian biopsies. Human Reproduction 21 1974-1980. (doi:10.1093/humrep/del109)

Hussein MR 2005 Apoptosis in the ovary: molecular mechanisms. Human Reproduction Update 11 162-177. (doi:10.1093/humupd/dmi001)

Janicke RU, Sprengart ML, Wati MR \& Porter AG 1998 Caspase-3 is required for DNA fragmentation and morphological changes associated with apoptosis. Journal of Biological Chemistry 273 9357-9360. (doi:10. 1074/jbc.273.16.9357)

Johnson NC, Dan HC, Cheng JQ \& Kruk PA 2004 BRCA1 185delAG mutation inhibits Akt-dependent, IAP-mediated caspase 3 inactivation in human ovarian surface epithelial cells. Experimental Cell Research 298 9-16. (doi:10.1016/j.yexcr.2004.04.003)

Kayamori T, Kosaka N, Miyamoto A \& Shimizu T 2009 The differential pathways of bone morphogenetic protein (BMP)-4 and -7 in the suppression of the bovine granulosa cell apoptosis. Molecular and Cellular Biochemistry 323 161-168. (doi:10.1007/s11010-008-9976-1)

Kumar S 2007 Caspase function in programmed cell death. Cell Death and Differentiation 14 32-43. (doi:10.1038/sj.cdd.4402060)

Lai KW, Cheng LY, Cheung AL \& O WS 2003 Inhibitor of apoptosis proteins and ovarian dysfunction in galactosemic rats. Cell Tissue Research 311 417-425.

Lareu RR, Lacher MD, Bradley CK, Sridaran R, Friis RR \& Dharmarajan AM 2003 Regulated expression of inhibitor of apoptosis protein 3 in the rat corpus luteum. Biology of Reproduction 68 2232-2240. (doi:10.1095/ biolreprod.102.013144)

Li J, Kim JM, Liston P, Li M, Miyazaki T, Mackenzie AE, Korneluk RG \& Tsang BK 1998 Expression of inhibitor of apoptosis proteins (IAPs) in rat granulosa cells during ovarian follicular development and atresia. Endocrinology 139 1321-1328. (doi:10.1210/en.139.3.1321)

Liston P, Fong WG, Kelly NL, Toji S, Miyazaki T, Conte D, Tamai K, Craig CG, McBurney MW \& Korneluk RG 2001 Identification of XAF1 as an antagonist of XIAP anti-Caspase activity. Nature Cell Biology 3 128-133. (doi:10.1038/35055027)

Lundy T, Smith P, O'Connell A, Hudson NL \& McNatty KP 1999 Populations of granulosa cells in small follicles of the sheep ovary. Journal of Reproduction and Fertility 115 251-262. (doi:10.1530/jrf.0. 1150251)

Mace PD, Shirley S \& Day CL 2009 Assembling the building blocks: structure and function of inhibitor of apoptosis proteins. Cell Death and Differentiation 17 46-53. (doi:10.1038/cdd.2009.45)

Matikainen T, Perez GI, Zheng TS, Kluzak TR, Rueda BR, Flavell RA \& Tilly JL 2001 Caspase-3 gene knockout defines cell lineage specificity for programmed cell death signaling in the ovary. Endocrinology 142 2468-2480. (doi:10.1210/en.142.6.2468)

Matsui T, Manabe N, Goto Y, Inoue N, Nishihara S \& Miyamoto H 2003 Expression and activity of Apaf1 and caspase-9 in granulosa cells during follicular atresia in pig ovaries. Reproduction 126 113-120. (doi:10. 1530/rep.0.1260113)

Moffatt-Blue CS, Sury JJ \& Young KA 2006 Short photoperiod-induced ovarian regression is mediated by apoptosis in Siberian hamsters (Phodopus sungorus). Reproduction 131 771. (doi:10.1530/rep.1.00870)

Nicholas B, Alberio R, Fouladi-Nashta AA \& Webb R 2005 Relationship between low-molecular-weight insulin-like growth factor-binding proteins, caspase-3 activity, and oocyte quality. Biology of Reproduction 72 796-804. (doi:10.1095/biolreprod.104.036087)

Olayioye MA, Kaufmann H, Pakusch M, Vaux DL, Lindeman GJ \& Visvader JE 2005 XIAP-deficiency leads to delayed lobuloalveolar development in the mammary gland. Cell Death and Differentiation 12 87-90. (doi:10.1038/sj.cdd.4401524)

Riedl SJ, Renatus M, Schwarzenbacher R, Zhou Q, Sun C, Fesik SW, Liddington RC \& Salvesen GS 2001 Structural basis for the inhibition of caspase-3 by XIAP. Cell 104 791-800. (doi:10.1016/S0092-8674(01) 00274-4)

Roy N, Mahadevan MS, McLean M, Shutter G, Yaraghi Z, Farahani R, Baird S, Besner-Johnston A, Lefebvre C \& Kang X 1995 The gene for neuronal apoptosis inhibitory protein is partially deleted in individuals with spinal muscular atrophy. Cell 80 167-178. (doi:10.1016/00928674(95)90461-1)

Roy N, Deveraux QL, Takahashi R, Salvesen GS \& Reed JC 1997 The C-IAP-1 and C-IAP-2 proteins are direct inhibitors of specific caspases. EMBO Journal 16 6914-6925. (doi:10.1093/emboj/16.23.6914) 
Scaramuzzi RJ, Adams NR, Baird DT, Campbell BK, Downing JA, Findlay JK, Henderson KM, Martin GB, McNatty KP, McNeilly AS et al. 1993 A model for follicle selection and the determination of ovulation rate in the ewe. Reproduction, Fertility, and Development 5 459-478. (doi:10.1071/RD9930459)

Scott FL, Denault JB, RiedI SJ, Shin H, Renatus M \& Salvesen GS 2005 XIAP inhibits caspase-3 and-7 using two binding sites: evolutionarily conserved mechanism of IAPs. EMBO Journal 24 645-655. (doi:10. 1038/sj.emboj.7600544)

Shimasaki S 2006 BMP15 regulation of ovulation quota in mammals. Reproductive Medicine and Biology 5 245-248. (doi:10.1111/j.14470578.2006.00148.x)

Shiozaki EN, Chai J, Rigotti DJ, Riedl SJ, Li P, Srinivasula SM, Alnemri ES, Fairman R \& Shi Y 2003 Mechanism of XIAP-mediated inhibition of caspase-9. Molecular Cell 11 519-527. (doi:10.1016/S10972765(03)00054-6)

Slee EA, Harte MT, Kluck RM, Wolf BB, Casiano CA, Newmeyer DD, Wang HG, Reed JC, Nicholson DW, Alnemri ES et al. 1999 Ordering the cytochrome c-initiated caspase cascade: hierarchical activation of caspases-2, $-3,-6,-7,-8$, and -10 in a caspase-9-dependent manner. Journal of Cell Biology 144 281-292. (doi:10.1083/jcb.144.2.281)

Sun C, Cai M, Gunasekera AH, Meadows RP, Wang H, Chen J, Zhang $\mathbf{H}$, Wu W, Xu N, Ng SC et al. 1999 NMR structure and mutagenesis of the inhibitor-of-apoptosis protein XIAP. Nature 401 818-822. (doi:10.1038/ 44617)

Sun C, Cai M, Meadows RP, Xu N, Gunasekera AH, Herrmann J, Wu JC \& Fesik SW 2000 NMR structure and mutagenesis of the third Bir domain of the inhibitor of apoptosis protein XIAP. Journal of Biological Chemistry 275 33777-33781. (doi:10.1074/jbc.M006226200)

Tamm I, Richter S, Scholz F, Schmelz K, Oltersdorf D, Karawajew L, Schoch C, Haferlach T, Ludwig WD \& Wuchter C 2004 XIAP expression correlates with monocytic differentiation in adult de novo $\mathrm{AML}$ : impact on prognosis. Hematology Journal 5 489-495. (doi:10.1038/sj. thj.6200549)

Uren AG, Beilharz T, O'Connell MJ, Bugg SJ, van Driel R, Vaux DL \& Lithgow T 1999 Role for yeast inhibitor of apoptosis (IAP)-like proteins in cell division. PNAS 96 10170-10175. (doi:10.1073/pnas.96.18. 10170)

Wang Y, Asselin E \& Tsang BK 2002 Involvement of transforming growth factor alpha in the regulation of rat ovarian X-linked inhibitor of apoptosis protein expression and follicular growth by follicle-stimulating hormone. Biology of Reproduction 66 1672-1680. (doi:10.1095/ biolreprod66.6.1672)

Wang Y, Rippstein PU \& Tsang BK 2003 Role and gonadotrophic regulation of $\mathrm{X}$-linked inhibitor of apoptosis protein expression during rat ovarian follicular development in vitro. Biology of Reproduction 68 610-619. (doi:10.1095/biolreprod.102.007807)

Wu G, Chai J, Suber TL, Wu JW, Du C, Wang X \& Shi Y 2000 Structural basis of IAP recognition by Smac/DIABLO. Nature 408 1008-1012. (doi:10. 1038/35050012)

Yang Y, Fang S, Jensen JP, Weissman AM \& Ashwell JD 2000 Ubiquitin protein ligase activity of IAPs and their degradation in proteasomes in response to apoptotic stimuli. Science $\mathbf{2 8 8} 874$. (doi:10.1126/science. 288.5467.874)

Received 25 May 2011

First decision 19 July 2011

Revised manuscript received 8 September 2011

Accepted 5 October 2011 